\title{
Reply: Expression of oestrogen receptor beta proteins in human breast cancer biopsies
}

\author{
PTK Saunders ${ }^{*, 1}$ and WR Miller ${ }^{2}$ \\ 'MRC Human Reproductive Sciences Unit, The University of Edinburgh Academic Centre, Edinburgh EHI 6 4SB, UK; ${ }^{2}$ Breast Cancer Research Unit, Western \\ General Hospital, Edinburgh EH4 2XU, UK
}

British Journal of Cancer (2002) 87, 688-689. doi:I0.1038/sj.bjc.6600535 www.bjcancer.com

(c) 2002 Cancer Research UK

\section{Sir}

We welcome the comments of Speirs and her co-workers concerning the variation and expression of $\operatorname{ER} \beta$ protein in breast cancer tissues as reported by ourselves (Saunders et al, 2002a) and Skliris et al (2001). Clearly, the differences may be caused by variations in sensitivity or specificity of the assays, or both, and it will be important to pinpoint the reason. If sensitivity (and the methodology which might lead to this is discussed below), then discrepancies may be resolved by determining appropriate cut-off values. On the other hand, differences in specificity may produce variations that are not simply related to $\operatorname{ER} \beta$ expression. It may therefore be useful to add the following perspective.

In our laboratory we have used a polyclonal antibody raised to hinge domain of $\mathrm{ER} \beta$ for several studies on human tissues (Critchley et al, 2001; Saunders et al, 2000). When this antibody was tested on breast tissue sections we detected expression of nuclear receptor in most sections within both normal and cancerous cells (unpublished observations). In 1998 two papers were published showing that several isoforms of $\operatorname{ER} \beta$ can be encoded by mRNAs formed by alternative splicing at the $3^{\prime}$ end of the gene (Moore et al, 1998; Ogawa et al, 1998). Furthermore, Ogawa et al (1998) showed that the protein of one of these forms $(\operatorname{Er} \beta \mathrm{cx} / \mathrm{ER} \beta 2)$, that lacks the ability to bind oestradiol, could be detected in tissue culture cells following transfection and could blunt the response to oestrogen if coexpressed with ER $\alpha$. Because the peptide used to raise our polyclonal antibody could recognise both the wildtype ER $\beta$ and this variant isoform we repeated our studies on breast tissue using a monoclonal antibody raised against the $\mathrm{C}$ terminus of full-length ER $\beta 1$ (Saunders et al, 2002a) which we have shown does not cross react with $\mathrm{ER} \beta \mathrm{cx} / \mathrm{ER} \beta 2$ (Saunders et al, 2002b). Although

\section{REFERENCES}

Critchley HOD, Brenner RM, Drudy TA, Williams KA, Nayak NR, Millar MR, Saunders PTK (2001) Estrogen receptor beta, but not estrogen receptor alpha, is present in the vascular endothelium of the human and nonhuman primate endometrium. J Clin Endocrinol Metab 86: $1370-1378$ the biological significance of the expression of $\operatorname{ER} \beta$ variant proteins is not known it is notable that expression of $\operatorname{ER} \beta c x$ has been reported to occur in prostatic cancers (Fujimura et $a l, 2001)$ and we have detected expression in breast cancer biopsies (Saunders, Miller manuscript in preparation). Immunohistochemical evaluations based on antibodies the specificity of which is not well defined may therefore lead to mis-interpretation of the likelihood that a tissue will respond to oestrogens via full-length $\mathrm{ER} \beta$.

In our experience there are two other factors that can have an adverse affect on the quality and reliability of detection of $\operatorname{ER} \beta$ protein namely tissue fixation and the specificity of secondary antibodies. Based on our experiences we believe poor tissue preservation (e.g. underfixation seen in the centre of large tissue fragments) and even over fixation (cross-linking of epitopes) can account for some of the variation in the detection of $\operatorname{ER} \beta$ reported over the last few years. Western analyses can also be problematic. We have found that $\operatorname{ER} \beta$ breaks down readily in solution and cannot withstand more than one freeze-thaw cycle, furthermore several secondary antibodies we have tried have given false positive bands, some with molecular weights close to $\mathrm{ER} \beta$, when tested on membranes without the addition of primary antibody.

Taking all these factors into account it is perhaps unsurprising that we are some way from deciding how the detection of ER $\beta$ should influence decisions regarding the oestrogenic responsiveness of tissues including the breast (and it is worth noting that the application of ER $\alpha$ required years of refinement). However, we are currently assessing the predictive value of our assay for $\operatorname{ER} \beta$ in tumours from patients with breast cancer receiving neo-adjuvant treatment with tamoxifen.
Fujimura T, Takahashi S, Urano T, Ogawa S, Ouchi Y, Kitamura T, Muramatsu M, Inoue S (2001) Differential expression of estrogen receptor beta (ERbeta) and its C-terminal truncated splice variant ERbetacx as prognostic predictors in human prostatic cancer. Biochem Biophys Res Commun 289: 692-699 
Moore JT, McKee DD, Slentz-Kesler K, Moore LB, Jones SA, Horne EL, Su JL, Kliewer SA, Lehmann JM, Willson TM (1998) Cloning and characterisation of human estrogen receptor beta isoforms. Biochem Biophys Res Commun 247: $75-78$

Ogawa S, Inoue S, Watanabe T, Orimo A, Hosoi T, Ouchi Y, Muramatsu M (1998) Molecular cloning and characterization of human estrogen receptor bcx: a potential inhibitor of estrogen action in human. Nucleic Acids Res 26: $3505-3512$

Saunders PT, Millar MR, Williams K, Macpherson S, Bayne C, O'Sullivan C, Anderson TJ, Groome NP, Miller WR (2002a) Expression of oestrogen receptor beta (ERbeta1) protein in human breast cancer biopsies. $\mathrm{Br} J$ Cancer 86: $250-256$
Saunders PTK, Millar MR, Macpherson S, Irvine DS, Groome NP, Evans LR, Sharpe RM, Scobie GS (2002b) Estrogen receptor beta (ER $\beta 1$ ), and the estrogen receptor beta 2 splice variant $(\operatorname{Er} \beta \mathrm{cx} / 2)$, are expressed in distinct cell populations in the adult human testis. J Clin Endocrinol Metab 87: $2706-2715$

Saunders PTK, Millar MR, Williams K, Macpherson S, Harkiss D, Anderson RA, Orr B, Groome NP, Scobie G, Fraser HM (2000) Differential expression of estrogen receptor-alpha and -beta and androgen receptor in the ovaries of marmoset and human. Biol Reprod 63: $1098-1105$

Skliris GP, Carder PJ, Lansdown MR, Speirs V (2001) Immunohistochemical detection of ERbeta in breast cancer: towards more detailed receptor profiling? Br J Cancer 84(8): 1095-1098

\section{Corrigendum}

\section{Heparanase is a prognostic indicator for postoperative survival in pancreatic carcinoma}

\section{J Rohloff, J Zinke, K Schoppmeyer, A Tannapfel, H Witzigmann, J Mössner, C Wittekind and K Caca}

British Journal of Cancer (2002) 87, 689. doi: 10.1038/sj.bjc.6600504 www.bjcancer.com

(c) 2002 Cancer Research UK

Correction to: British Journal of Cancer (2002) 86, 1270. doi:10.1038/sj/bjc/6600232

The authors would like to thank InSight Ltd., Rehovot, Israel for providing them with the anti-heparanase antibody and heparanase cDNA used in the study.

The mentioned reagents are proprietary of InSight. 